\title{
Physical and chemical characteristic of stem starch and sheath flour from oil palm tree (Elaeis guineensis)
}

\author{
SYARIFAH YUSRA ${ }^{1, \vartheta}$, YUDI PRANOTO ${ }^{2}$, CHAIRIL ANWAR ${ }^{3}$, CHUSNUL HIDAYAT $^{2, \bullet v}$ \\ ${ }^{1}$ Department of Agrotechnology, Faculty of Agricultural, Universitas Sains Cut Nyak Dhien, Jl. A. Yani. Langsa, Nangro Aceh Darussalam, Indonesia, \\ vemail: yusraalydrus@gmail.com \\ ${ }^{2}$ Department of Food and Agricultural Product Technology, Faculty of Agricultural Technology, Universitas Gadjah Mada, J1. Sosio-Yustisia, \\ Bulaksumur, Yogyakarta 55281, Indonesia. Tel: +62-274-549650, Fax: +62-274-549650, vemail: chusnul@gadjahmada.edu \\ ${ }^{3}$ Department of Chemistry, Faculty of Mathematics and Sciences, Universitas Gadjah Mada, Jl. Sekip Utara Bulaksumur Yogyakarta 55281, Indonesia
}

Manuscript received: 28 October 2019. Revision accepted: 6 February 2020.

\begin{abstract}
Yusra S, Hidayat C, Pranoto Y, Anwar C. 2020. Physical and chemical characteristics of stem starch and sheath flour from oil palm tree (Elaeis guineensis). Biodiversitas 21: 896-902. Replanting old oil palm plantation with a new plant produces a large volume of cleared trees. Yet, the utilization of these by-products is still limited. The objective of this research was to explore and characterize the physicochemical properties of the oil palm stem starch (SS) and sheath flour (SF). SF and SS were extracted by a wet extraction method. Results showed that starch contents of SS and SF (after three times of washing) were 95.56 $\pm 0.01 \%$ and $37.03 \pm$ $0.72 \%$, respectively. Amylose and amylopectin contents of SS were higher than that of sheath starch. Besides, SF contained high protein $(19.28 \% \mathrm{db})$ and lipid $(9.27 \% \mathrm{db})$. Protein was also confirmed by FTIR analysis. SF also contained polyphenol. The starch granular was smooth with a clean surface. The granules of SF are classified as very small granules $(2-5 \mu \mathrm{m})$ while those of SS as small to medium granules $(5-25 \mu \mathrm{m})$. Polymorph analysis showed that SF and SS had a type-C and B-type, respectively. SF did not have pasting temperature due to the presence of lipid, protein, and polyphenol. Washing of the flour with water decreased protein, lipid and ash contents. It resulted in a decrease in yield about 1.8 times. SS has a pasting temperature of about $71.55^{\circ} \mathrm{C}$. Paste viscosity reached a maximum of about $5707 \mathrm{cps}$. In conclusion, SS that had high viscosity may be used as a thickener and SF may be used for a source of the modified starch to produce such as dextrin and glucose syrup.
\end{abstract}

Keywords: Oil palm, physicochemical, sheath flour, stem starch

\section{INTRODUCTION}

Oil palm (Elaeis guineensis) is one of the major crops that contribute to the economic growth of Indonesia. In this country, the total extent of oil palm plantation was about 10.9 million ha in 2014 which produced 29.3 million tons of crude palm oil (CPO) (Direktorat Jenderal Perkebunan 2015). In 2015 and 2017 the area increased to about 11.2 million ha and 12.3 million ha, respectively (Idris et al. 2018).

After reaching its productive stage at 25-30 years old, oil palm has to be replanted with a new plant (Lamaming et al. 2015a), leaving the old palm trees as waste. So far, the cleared old oil palm trees are under-utilized because the mechanical properties of the trunk are weak due to the high concentration of carbohydrates. It cannot be used for woodbased materials and furniture, as such most of the trees are burned or used as landfills. In some cases, the trees are injected with chemicals into the roots, which potentially cause environmental pollution (Hamid et al. 2015).

In general, an oil palm tree can be divided into two parts, namely sheath (i.e. the top part of the tree), and stem (i.e. the middle and bottom parts of the tree). Total raw materials in the form of stem and sheath of trunk are about $6,315,543$ and $1,439,440$ tons in a year, respectively (Ridwansyah et al. 2010). The stem consists of vascular bundle and parenchyma tissue that acts as food storage and transportation organs, respectively (Lamaming et al. 2015a; Bakar et al. 2012; Sulaiman et al. 2012; Abe et al. 2014). The inner part of the stem is composed of $70 \%$ of parenchyma cortex tissue (Bakar et al. 2012), while the outer part of stem is largely composed of vascular bundle, providing support mechanically and transporting nutrients and water (Lamaming et al. 2015b). The composition of a vascular bundle is fiber, xylem, vessels, sieve tube, protoxylem, stomata, axial parenchyma and companion cells (Sulaiman et al. 2012; Abe et al. 2014). Abe et al. (2014) added that the cells parenchyma stores food reserve such as carbohydrates, mostly in the form of sugar and starch. Starch concentration is higher in the core of the oil palm trunk than that of the outer part, and it increases with the increase in height (Tomimura 1999; Abe et al. 2014).

On the other hand, sheath produced by the old oil palm plant cleared for replanting is mostly used as cattle feed since it contains a high concentration of glucose (Idris et al. 2018). The decomposition of oil palm sheath in the field is fast and can cause the occurrence of pests, which is harmful to the new plants. Despite these facts, oil palm sheath has nutritional potentials.

Research on the characterization of stem starch (SS) of oil palm has been reported by only a few researchers (Azemi and Noor 1999; Tomimura 1999; Ridwansyah et al. 2010) while there is no study about oil palm sheath flour (SF). This study aimed to characterize SF and SS from the 
oil palm tree and to explore the potentials of flour and starch produced from oil palm trees for food. We did this by extracting SF and SS using a wet extraction method and the products were further analyzed on its physical and chemical properties.

\section{MATERIALS AND METHODS}

\section{Materials}

The materials of stem and sheath of oil palm were obtained from \pm 25 years old oil palm planted on Plantation Research, Politeknik Perkebunan Yogyakarta, Yogyakarta Special Province, Indonesia.

\section{Extraction of stem starch and sheath flour}

The extraction of stem starch was started by removing the bark of oil palm stem. The core was crushed in a blender and then water was added to produce pulp. The pulp was macerated and filtered using filter cloth to produce starch. The starch was then precipitated for 3 hours and dried for 24 hours at $50^{\circ} \mathrm{C}$.

The extraction of oil palm sheath was started by separating petioles from oil palm sheath and the sheath was cut into $1 \times 1 \mathrm{~cm}^{2}$ pieces. Water was added into sheath chips and crushed in a blender to produce pulp. The pulp was macerated and then filtered using filter cloth to produce flour. The flour was precipitated for 6 hours and further dried at $50^{\circ} \mathrm{C}$.

\section{Characterization of stem starch and sheath flour}

The stem starch (SS) and sheath flour (SF) were characterized to reveal its water content, ash content, protein content, fat content, amylose content, and starch content according to the AOAC method (AOAC 2005). The color intensity of SF was determined using a Konica Minolta CM-400 spectrophotometer (Osaka, Japan). The color characteristics were analyzed based on $\mathrm{L}^{*}$ (lightness), a* (redness), and b* (yellowness).

\section{Scanning electron microscopy (SEM)}

The microstructure of SS and SF granules were analyzed using SEM-EDS (JEOL JSM-6510 LA) according to Nakthong et al. (2017). The analysis was carried out under vacuum on acceleration voltage $15 \mathrm{kV}$. Samples were placed on aluminum stubs and then coated with goldpalladium for 10 minutes. The coated sample was placed on a SEM microscope and observed at 5000X magnification.

\section{Spectra of Fourier Transform Infrared (FTIR)}

Fourier Transform Infrared (FTIR) Spectra of starch and flour sample were analyzed using Thermo Nicolet i50 FTIR spectrometer (Waltham, MA) according to Kizil et al. (2002). The sample was mixed with KBr. FTIRs Spectra were obtained at wavenumbers of $400 \mathrm{~cm}^{-1}$ to $4000 \mathrm{~cm}^{-1}$.

\section{Determination of sheath flour and stem starch by $X$ - Ray diffraction (XRD)}

The starch crystallinity of SS and SF was analyzed by X-ray diffraction pattern (FR 592 Delft, Netherlands), at $\mathrm{Cu}-\mathrm{k} \alpha$ radiation $(\lambda 1.5406 \AA), \mathrm{X}$-ray $40 \mathrm{kV}$, and $30 \mathrm{~mA}$ according to Dankar et al. (2018). The diffraction angles were ranging from $2 \theta, 3-30^{\circ}$.

\section{Pasting properties}

The pasting properties of SS and SF were measured using Rapid Visco Analyzer (RVA) according to Nakthong et al. (2017). About $3.0 \mathrm{~g}$ sample was weighed in an RVA container. Water $(25.0 \mathrm{~g})$ was then added to the sample. Flour suspension was stirred at $160 \mathrm{rpm}$ and heated from $50^{\circ} \mathrm{C}$ to $95^{\circ} \mathrm{C}$ at increasing speed of $6^{\circ} \mathrm{C} / \mathrm{min}$. The temperature was then maintained at $95^{\circ} \mathrm{C}$ for $5 \mathrm{~min}$. Subsequently, the paste was cooled at a cooling speed of $6^{\circ} \mathrm{C} / \mathrm{min}$ from $95^{\circ} \mathrm{C}$ to $50^{\circ} \mathrm{C}$. The temperature was then maintained at $50^{\circ} \mathrm{C}$ for $2 \mathrm{~min}$.

\section{RESULTS AND DISCUSSION}

\section{Characterization of stem starch and sheath flour}

The compositions of stem starch (SS) and sheath flour (SF) of oil palm are shown in Table 1. The starch content of the sheath product was 7.12 times lower than that of stem products. Therefore, sheath product is categorized as flour and stem product is as starch. SF contained a protein, lipid, and ash about 32.1, 46.3 and 17.4 times higher than that of SS, respectively. As a consequence, the carbohydrate content of SS was 1.8 times higher than that of SF. SS has higher amylose and amylopectin contents than SF. The purity of SS was higher than SF since it contained $86.11 \%$ carbohydrate, in which most of the carbohydrate was containing of $95.56 \%$ starch (Table 1).

A similar result was reported on sago starch (Singhal et al. 2008), in which the stem of the sago trunk contained amylose higher than the top part of the trunk. It is suggested that SF contained other components such as polyphenol, protein, fat, and ash since the brightness of the starch was lower than SS (Table 1).

Table 1. The composition of stem starch and sheath flour

\begin{tabular}{lll}
\hline Components & Stem Starch & Sheath Flour \\
\hline Moisture $(\% \mathrm{db})$ & $10.82 \pm 0.15$ & $12.47 \pm 0.95$ \\
Protein $(\% \mathrm{db})$ & $0.59 \pm 0.01$ & $19.28 \pm 0.21$ \\
Lipid $(\% \mathrm{db})$ & $0.19 \pm 0.02$ & $9.27 \pm 0.42$ \\
Ash $(\% \mathrm{db})$ & $0.65 \pm 0.02$ & $11.29 \pm 1.37$ \\
Carbohydrate $(\% \mathrm{db})$ & $86.11 \pm 0.06$ & $47.69 \pm 0.52$ \\
Starch $(\% \mathrm{db})$ & $95.56 \pm 0.01$ & $13.41 \pm 0.08$ \\
Amylose $(\% \mathrm{db})$ & $36.38 \pm 1.18$ & $6.04 \pm 0.33$ \\
Amylopectin $(\% \mathrm{db})$ & $58.98 \pm 0.82$ & $7.37 \pm 0.17$ \\
Color & & \\
L* & $86.50 \pm 0.11$ & $60.79 \pm 0.26$ \\
a* & $4.44 \pm 0.01$ & $8.55 \pm 0.04$ \\
b* & $1.67 \pm 0.08$ & $18.99 \pm 0.12$ \\
Yield $(\%)$ & $7.46 \pm 0.44$ & $1.1 \pm 0.05$ \\
\hline Note: Data are expressed as mean \pm standard deviation $(\mathrm{n}=3)$
\end{tabular}




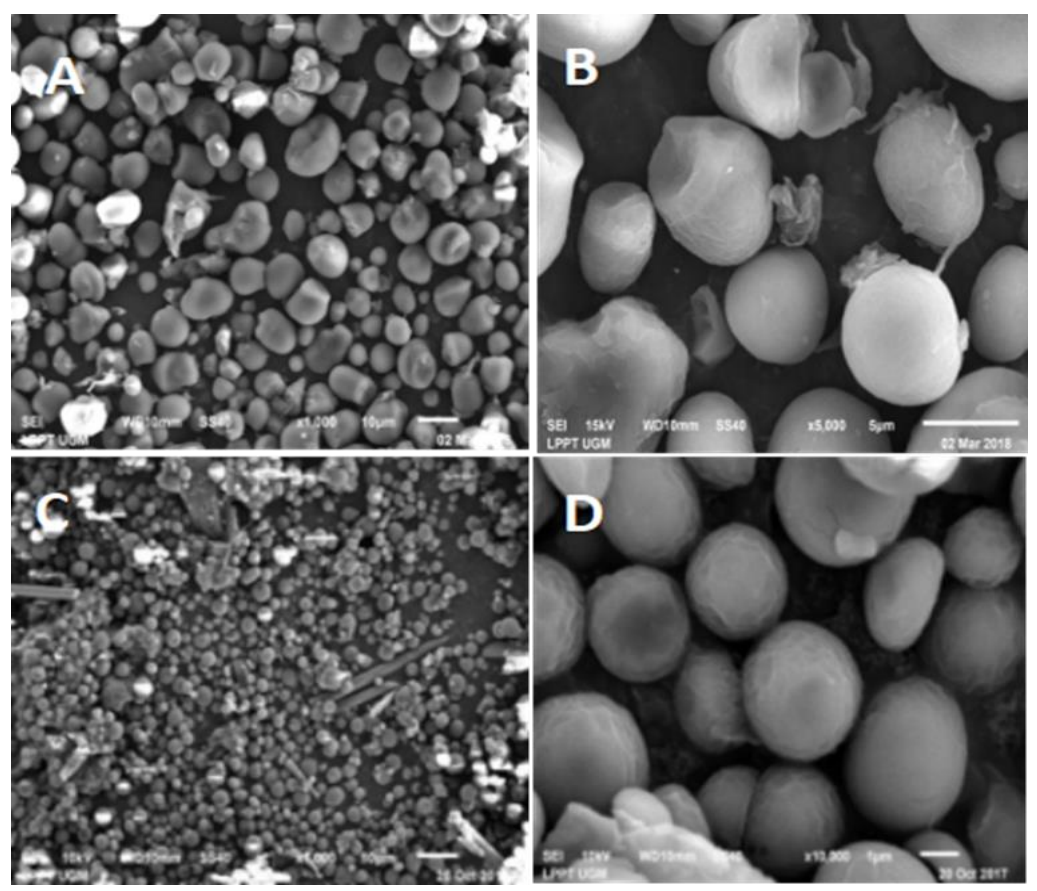

Figure 1. Scanning electron micrograph of the granules. A. Stem starch with 1,000X magnification); B. Stem starch with 5,000X magnification; C. Sheath flour with 1,000X magnification; and D. Sheath flour with 10,000X magnification.

Previous studies also suggested that the brightness of the starch was caused by those compounds (Pei-lang et al. 2006). On the other hand, the yield of SS was 6.8 times higher than SF. The starch yield of the sheath was lower due to the higher water content of the sheath. Azemi and Noor (1999) also reported that various wet extractions of starch from the stem had a maximum yield of about $7.15 \%$.

\section{Washing of sheath flour}

The brightness of SF was low (Table 1). The L-value of sheath flour was about 60.79. Washing of the flour with water improved the brightness (Table 2). It is likely that the low brightness was mostly due to the high concentration of polyphenol. Polyphenol concentrations in the washed water after washing were about $78 \mathrm{~mL} / \mathrm{L}$ AGE, $11.54 \mathrm{~mL} / \mathrm{L}$ AGE and $0.45 \mathrm{~mL} / \mathrm{L}$ AGE for first, second and third flour washing, respectively. Polyphenol content was not detected in the washed water after the third washing. As a result, the brightness of SF increased about 1.2 times after washing.

While increasing brightness, washing of the flour with water decreased protein, lipid and ash contents (Table 2). However, the ash content did not decrease significantly after the second washing. As a result, three times flour washing increased the starch content about 2.7 times. However, leaching of some components during washing resulted in a decrease in flour yield about 1.8 times.

\section{Scanning electron microscopy (SEM)}

The size and morphology of starch or flour granules depend on the type of plant. The scanning electron of the starch and flour granules is shown in Figure 1. The granules of stem starch and sheath flour were spherical, oval, round and rather smooth surface. Diameters of sheath flour granules were about 2-5 $\mu \mathrm{m}$. They were smaller than that of stem starch granules $(5-25 \mu \mathrm{m})$. It is suggested that starch is synthesized through the synthesis of glucose in the leaf. Glucose is transferred from the leaf to cells in the sheath part. Therefore, the sheath part of the plant contained high glucose content than stem (Idris et al. 2018). Furthermore, the glucose is converted to starch and it is stored in parenchyma cells (Tomimura et al. 1992; Lamaming et al. 2015b). The sheath part contains fewer parenchyma cells than the stem part (Hamid et al. 2015; Abe et al. 2014; Omar et al. 2011). Therefore, the stem part has more starch and bigger granules than that of the sheath (Figure 1). Besides, the size of the granules has an effect on the improving of starch properties, such as the temperature of gelatinization, the power of swelling and viscosity (Singh and Singh 2003). It is suggested that large-size granules are more appropriate for applications in the food industry due to better pasta properties.

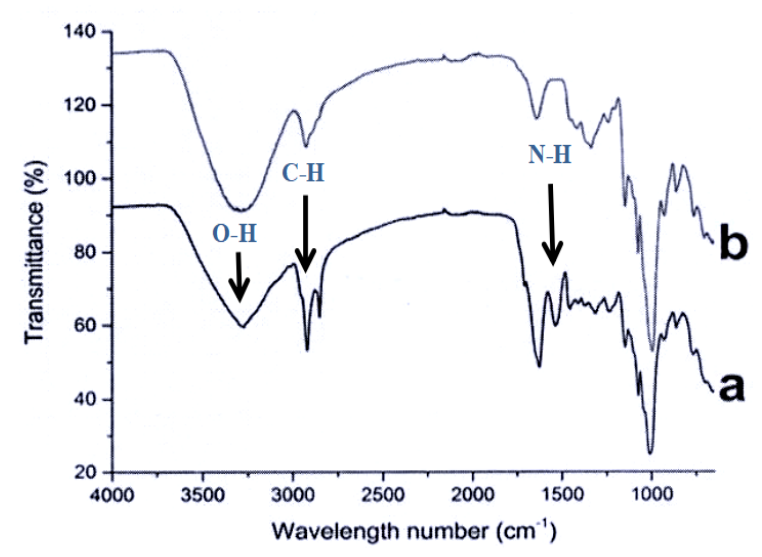

Figure 2. The FTIR Spectra of sheath flour (A) and stem starch (B) 
Table 2. The composition of sheath flour after washing

\begin{tabular}{lllll}
\hline Component & \multicolumn{3}{c}{ Sheath flour } \\
\cline { 2 - 5 } & Before washing & First washing & Second washing & Third washing \\
\hline Moisture $(\% \mathrm{db})$ & $12.47 \pm 0.95$ & $10.23 \pm 0.07$ & $10.48 \pm 0.52$ & $7.47 \pm 0.05$ \\
Protein $(\% \mathrm{db})$ & $19.28 \pm 0.21$ & $15.94 \pm 0.50$ & $14.36 \pm 0.04$ & $11.88 \pm 0.55$ \\
Lipid $(\% \mathrm{db})$ & $9.27 \pm 0.42$ & $8.17 \pm 1.99$ & $7.94 \pm 0.92$ & $7.68 \pm 0.84$ \\
Ash $(\% \mathrm{db})$ & $11.29 \pm 1.37$ & $10.36 \pm 1.30$ & $8.87 \pm 0.14$ & $8.43 \pm 0.18$ \\
Carbohydrate $(\% \mathrm{db})$ & $47.69 \pm 0.52$ & $55.3 \pm 0.85$ & $58.36 \pm 0.4$ & $37.5 \pm 0.35$ \\
Starch $(\% \mathrm{db})$ & $13.41 \pm 0.08$ & $21.31 \pm 0.38$ & $36.72 \pm 0.01$ & $16.15 \pm 0.42$ \\
Amylose $(\% \mathrm{db})$ & $6.04 \pm 0.33$ & $12.37 \pm 0.26$ & $13.38 \pm 0.13$ & $20.88 \pm 0.21$ \\
Amylopectin & $7.37 \pm 0.17$ & $8.94 \pm 0.08$ & $23.34 \pm 0.08$ & $73.70 \pm 0.08$ \\
Color & & & & $6.05 \pm 0.01$ \\
L* & $60.79 \pm 0.26$ & $68.82 \pm 0.9$ & $73.48 \pm 0.11$ & $13.73 \pm 0.05$ \\
a* & $8.55 \pm 0.04$ & $5.28 \pm 0.31$ & $6.32 \pm 0.51$ & $0.6 \pm 0.02$ \\
b* & $18.99 \pm 0.12$ & $13.96 \pm 0.05$ & $13.77 \pm 0.03$ & $0.8 \pm 0.02$ \\
Yield & $1.1 \pm 0.05$ & $0.95 \pm 0.05$ & & \\
\hline Net & & & &
\end{tabular}

Note: Data are expressed as mean \pm standard deviation $(\mathrm{n}=3)$

Therefore stem starch was easy to be separated than that of sheath flour. In general, the size of granules is classified into four groups: very small $(<5 \mu \mathrm{m})$, small $(5-10 \mu \mathrm{m})$, medium $(10-25 \mu \mathrm{m})$, large $(>25 \mu \mathrm{m})$ (Fauziah et al. 2016). Thus sheath flour is classified as very small granule and stem starch is classified as small to medium granule.

\section{Characteristics of functional groups (FTIR)}

FTIR spectra analysis of SS and SF is shown in Figure 2. The SS and SF had a peak at the wavenumber of 3271 $\mathrm{cm}^{-1}$. This confirmed the presence of an $\mathrm{OH}$ group of the starch molecules. In general, the peak at wavenumber $3000-3700 \mathrm{~cm}^{-1}$ is associated with strong absorption of $\mathrm{OH}$ group, which indicated a high concentration of carbohydrate (Xing et al. 2014; Hamid et al. 2015; An et al. 2011; Wang et al. 2015). However, the peak of SF was sharper than that of $\mathrm{SS}$, indicating that there was a $\mathrm{NH}$ group in SF. Besides, SF had also a peak at $1537 \mathrm{~cm}^{-1}$, which related to an amide group. But this peak was not detected in SS. Thus, this confirmed that SF contained high protein (Table 1).

$\mathrm{SF}$ had a peak at 2920.35 and $2850.83 \mathrm{~cm}^{-1}$. However, SS has only a peak at $2850.83 \mathrm{~cm}^{-1}$. In general, the aliphatic C-H vibrations mostly occurred at the wavenumber of $2850-2960 \mathrm{~cm}^{-1}$. This band is assigned as the stretching vibration of the $\mathrm{C}-\mathrm{H}$ bond of glucose units (Cruz et al. 2017). Thus it confirmed the presence of the aliphatic C-H vibrations of glucose unit. It is suggested that the peak at $2920.35 \mathrm{~cm}^{-1}$ is related to the presence of proteins (Cruz et al. 2017; Lian et al. 2014).

The peak difference in FTIR spectra between 800 and $1500 \mathrm{~cm}^{-1}$ shows the most important structural differences in starch (Figure 2) because the changes in polymeric structure and conformation of starch are shown in this band. Polysaccharides, such as starch, absorbed infra-red at wavenumbers of $1200-800 \mathrm{~cm}^{-1}$, which is the fingerprint of starch conformation and hydration (Dankar et al. 2018). Furthermore, the wavenumber between 1022 and $1048 \mathrm{~cm}^{-1}$ indicates the amorphous and crystal region of starch
(Dankar et al. 2018). In the case of SF and SS, the peak intensity at a wavenumber of $999 \mathrm{~cm}^{-1}$ is relatively higher compared with $1011 \mathrm{~cm}^{-1}$. Thus, the conformation of the SF is more amorphous than the crystal. This was also confirmed by the higher intensity of the peak in SF $(1632.51 \mathrm{~cm}-1)$ than SS $\left(1626.77 \mathrm{~cm}^{-1}\right)$. It indicated water absorption in the amorphous region of starch in the presence of $\mathrm{C}=\mathrm{O}$ group. The secondary structure of starch was also observed in the wavenumber region from 930 to $500 \mathrm{~cm}^{-1}$. SF and SS had infrared absorption at wavenumbers from 929.77 to $861.25 \mathrm{~cm}^{-1}$ and from 929.38 to $702.49 \mathrm{~cm}^{-1}$, respectively. These peaks are the vibration of the alpha (1-4) glycosides linkage, skeletal modes of the C-C stretch and the skeletal modes of the pyranose ring (Dankar et al. 2018).

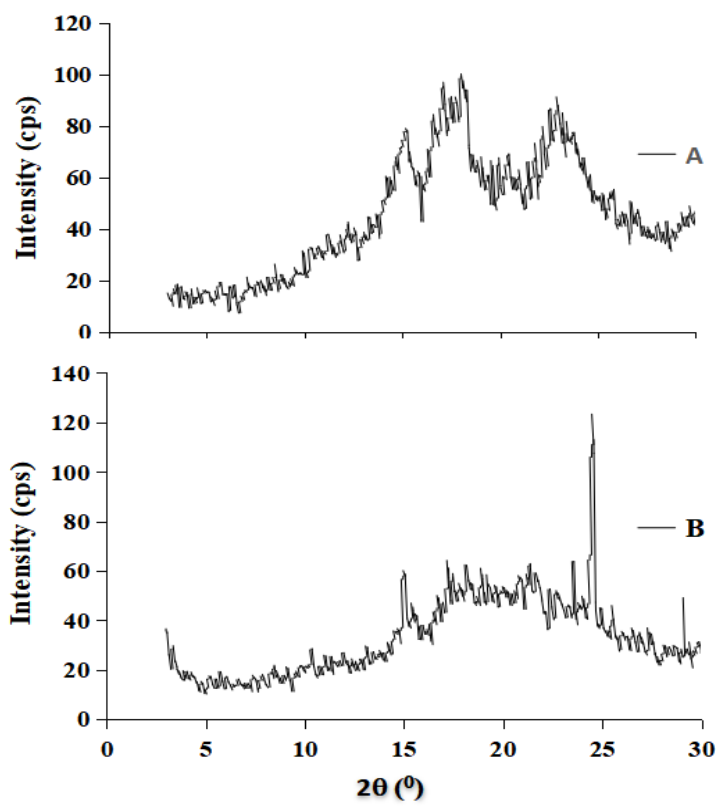

Figure 2. X-Ray Diffraction pattern of stem starch (A) and sheath flour (B) 


\section{X-ray diffraction (XRD)}

The X-ray diffraction pattern is shown in Figure 3. SF had peak values at $15.05^{\circ}, 17.93^{\circ}, 18.94^{\circ}$ and a strong peak at $24.49^{\circ}$ (Figure 3A). On the other hand, SS had peak values at $15.24^{\circ}, 17^{\circ}, 18.03^{\circ}$ and a strong peak at $22.93^{\circ}$ (Figure 3B). In general, the starch crystal is classified as A, B or C types. A-type starch has a monoclinic crystal of parallel stranded. B-type starch has double helices of hexagonal arrangement while C-type starch has a characteristic as A and B-type starch (Nakthong et al. 2017). A-type starch at Bragg angle (2 $\theta$ ) has a sharp peak at $15.2^{\circ}$, two peaks at $17.3^{\circ}$ and $18.1^{\circ}$, and a strong peak at $23.3^{\circ}$ (Lian et al. 2014). B-type has sharp peaks at $5.6^{\circ}, 15^{\circ}$, and $17^{\circ}$, strong peaks at $22^{\circ}$ and $24^{\circ}$. It is suggested that the SS type is B-type (Bpolymorph) and sheath starch is a type-C (starch combination A and B-type). Nakthong et al. (2017) reported that short-chain branches amylopectin of starch ( $20<$ residue) was responsible for A-type crystallinity (Apolymorph) while the starch with long-chain branches exhibit B-polymorph. The content of amylose in SS was high enough (Table 1). The crystallinity of SF (34.3\%) was higher than that of SS $(32.25 \%)$. It is suggested that the presence of several components, such as proteins, lipids, and cellulose resulted in an increase in the crystallinity of SF (Bi et al. 2017).

\section{Pasting properties of washed sheath flour}

The pasting curves of washed SF are presented in Figure 4. SF did not have pasting temperature. First, second and third washing improved the pasting temperature to 80,80 and $73^{\circ} \mathrm{C}$, respectively. However, the paste viscosity was still very low. It is suggested that lipid, protein and polyphenol contents (Table 1) depressed pasting temperature of the starch. Lipids in starch granules can significantly reduce the swelling capacity of the starch paste (Morrison et al.1987). Besides, low viscosity is caused by the small diameter of SF and low carbohydrate content (Figure 1). Washing of starch improved the viscosity (Figure 4). The highest viscosity was obtained after the third washing. However, the viscosity is still low compared with other starches (Tu et al. 1979) due to the low content of amylose and amylopectin (Table 2).

Peak viscosity (PV), trough viscosity (TV), final viscosity (FV), and setback viscosity (SV) curves increased with an increase in washing steps (Figure 4). The three washing caused an increase in TV about 3.4 times compared to unwashed SF. FV increased about 38, 46, 80 $\mathrm{cPs}$, respectively. It is suggested that pasting properties of sheath flour is affected by various factors, such as amylose, protein, fat contents, and granule size (Aini et al. 2010). Sheath flour washing released protein and lipid and increased starch content (Tabel 2). As a consequence, it improved the starch swelling capacity and further increased PV, TV and FV values. Besides, cooling caused the re-association of starch molecules (especially linear chains such as amylose), which results in gel structure formation and an increase in final viscosity due to retrogradation.

\section{Pasting properties of stem starch}

SS granules started to swell at a temperature of $71.55^{\circ} \mathrm{C}$ (pasting temperature) and followed by an increase in suspension viscosity during the heating phase (Figure 5). Starch swelling indicated that starch suspension started to gelatinize. Viscosity reached a maximum of about 5707 cps. It is suggested that high viscosity of starchy pasta is due to large starch granules (Figure 1). A large granule size causes a greater water-absorbing capability. Further heating at a constant temperature resulted in a decrease in viscosity due to the disruption of starch granules.

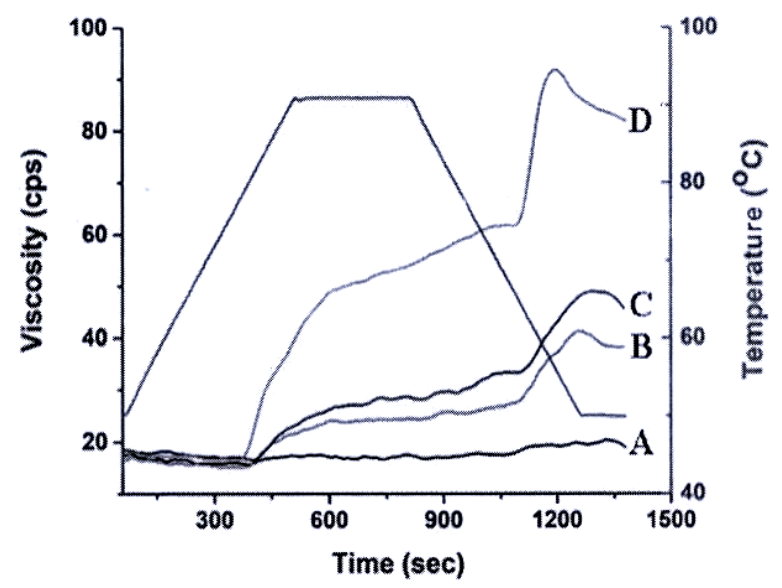

Figure 4. Effect of washing on the pasting properties of sheath flour. Pasting properties analysis was performed using Rapid Visco Analyzer for sheath flour before washing (A), first washing (B), second washing (C), and third washing (D)

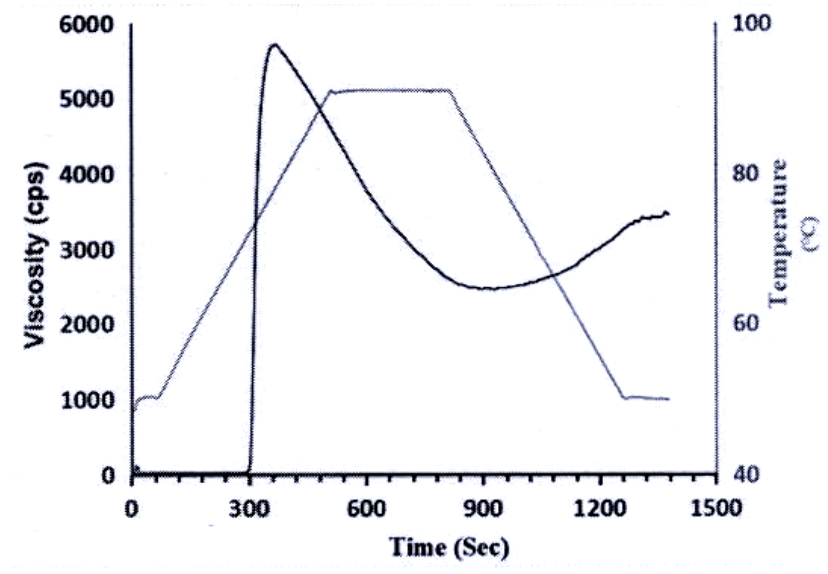

Figure 5. Pasting properties of stem starch. The analysis was performed using a Rapid Visco Analyzer 
Thirumdas et al. (2017) reported that the destruction or loosen of starch granule structures due to starch swelling resulted in higher peak viscosity (PV) and low-temperature paste (PT). SS has a high setback viscosity compared to SF (Figure 4) during cooling. It is suggested that an increase in viscosity of SS paste during cooling is due to the reassociation of amylose and amylopectin molecules of SS by hydrogen bonding ( $\mathrm{Tu}$ et al. 1979; Thirumdas et al. 2017). An increase in viscosity during the cooling phase indicated a retrogradation of SS paste.

In general, pasting temperature of starches is around $64-82^{\circ} \mathrm{C}$ and peak viscosity is around $253-510 \mathrm{cps}$ (Suh and Jane 2003). However, SS has both relatively higher peak viscosity and end viscosity (Figure 5). It is suggested that SS can be used as thickener agent and a source of the modified starch for application in both food and non-food industry. On the other hand, SF had law peak viscosity and did not have pasting temperature. Thus it can not be used as a source of starch in food industry, but it may be used for a source of the modified starch to produce such as dextrin and glucose syrup.

In conclusion, granules produced from sheath are categorized as flour but those of stem is as starch since starch content of sheath and stem products were $13.41 \pm$ $0.08 \%$ and $95.56 \pm 0.01 \%$, respectively. The sheath flour (SF) had a high content of protein and lipid in which the protein was confirmed by FTIR analysis. The flour also contained polyphenol. Therefore, the brightness of the starch was low. The starch content of SF increased to 37.03 $\pm 0.72 \%$ after three times of washing. SF granule is classified as a very small granule $(2-5 \mu \mathrm{m})$ while SS granule is classified as small to medium granule $(5-25 \mu \mathrm{m})$. Polymorph analysis showed that SF was a type-C and the SS type was B-type (B-polymorph). SF did not have pasting temperature. Washing of SF with water decreased protein, lipid and ash contents. However, leaching of some components during washing resulted in a decrease in yield about 1.8 times. SS has a pasting temperature of about $71.55^{\circ} \mathrm{C}$. Paste viscosity reached a maximum of about 5707 cps.

\section{ACKNOWLEDGMENTS}

This research was supported by "Beasiswa Pendidikan Pascasarjana Dalam Negeri (BPPDN)", the Ministry of Research, Technology, and Higher Education of Republic of Indonesia.

\section{REFERENCES}

Abe H, Murata Y, Kubo S, Watanabe K, Tanaka R, Sulaiman O, Hashim R, Ramle SFM, Zhang C, Noshiro S, Mori Y. 2014. Estimation of the ratio of vascular bundle to parenchyma tissue in oil palm trunks using NIR spectroscopy. BioResources 8 (2): 1573-1581.

Aini N, Wijonarko G, Sustriawan F. 2016. Physical, chemical, and functional properties of cornflour processed by fermentation. Agritech 36 (2): 160-169.
An N, Thien NT, Dong DT, Dung NT, Du, PL. 2011. Isolation and characteristics of polysaccharide from Amorphophallus Corrugatus in Vietnam. Carbohydr Polym 84 (1): 64-68.

AOAC. 2005. Official methods of analysis of the association of official analytical chemists. Association of Official Analytical Chemist, Arlington, VA., USA.

Azemi M, Noor M. 1999. Physico-chemical properties of oil palm trunk starch. Starch/Stärke 51 (108): 13-18.

Bakar BFA, Paridah MT, Karimi A, Bakar ES, Uyup MKA, Choo ACY. 2012. Evaluations of some physical properties of oil palm as alternative biomass resources. J Wood Mater Sci Eng 8 (2): 119-128.

Bi Y, Zhang Y, Jiang H, Hong Y, Gu Z, Cheng, L, Li Z, Li C. 2017. Molecular structure and digestibility of banana flour and starch. Food Hydrocoll 72: 219-227.

Cruz LG, Soto JLM, Barajas EC, Rodríguez MDLLXN, Morales AF, Nicanor AB. 2017. Spectroscopic, calorimetric and structural analyses of the effects of hydrothermal treatment of rice beans and the extraction solvent on starch characteristics. Int J Biol Macromol 107: 965-972.

Dankar I, Haddarah A, Omar FEL, Sepulcre F. 2018. Characterization of food additive-potato starch complexes by FTIR and X-ray diffraction. Food Chem 260: 7-12.

Direktorat Jenderal Perkebunan. 2015. Statistik perkebunan Indonesia komoditas kelapa sawit. Direktorat Jenderal Perkebunan, Jakarta. [Indonesia]

Fauziah, Mas'udah S, Hendrian. 2016. Study on the starch granules morphology of local varieties of Dioscorea hispida and Dioscorea alata. J Trop Life Sci 6 (1): 47-52

Hamid ZA, Arai T, Fatimah MRS, Kosugi A, Sulaiman O, Hashim R, Nirasawa S, Ryohei T, Lokesh BE, Sudesh K, Murata Y. Saito M, Mori Y. 2015. Analysis of free sugar and starch in oil palm trunks (Elaeis guineensis Jacq.) from various cultivars as a feedstock for bioethanol production. Int J Green Energy https://doi.org/10.1080/15435075.2014.910786.

Idris M, Karo TK, Rusmarilin H. 2018. Pengaruh umur setelah penebangan dan letak umbut pada batang terhadap potensi umbut kelapa sawit (Elaeis guineensis Jacq.) sebagai bahan pangan. J Rekayasa Pangan Pertanian 6 (1): 18-25. [Indonesian]

Kizil K, Irudayaraj J, Seetharaman K. 2002. Characterization of irradiated starches by using FT-Raman and FTIR spectroscopy. J Agric Food Chem 50: 3912-3918

Lamaming J, Hashim R, Sulaiman O, Leh C, Sugimoto T, Nordin NA. 2015a. Cellulose nanocrystals isolated from oil palm. Carbohydr Polym 127: 202-208.

Lamaming J, Hashim R, Peng C, Sulaiman O, Sugimoto T, Nasir M. $2015 \mathrm{~b}$. Isolation and characterization of cellulose nanocrystals from parenchyma and vascular bundle of oil palm trunk (Elaeis guineensis). Carbohydr Polym 134: 534-540.

Lian X, Wang C, Zhang K, Li L. 2014. The retrogradation properties of glutinous rice and buckwheat starches as observed with FT-IR 13C NMR and DSC. Int J Biol Macromol 64: 288-293.

Morrison WR, Azudin MN. 1987. Variation in the amylose and lipid contents and some physical properties of rice starches. J Cereal Sci 5 (1): 35-44.

Nakthong N, Wongsagonsup R, Amornsakchai T. 2017. Characteristics and potential utilization of starch from pineapple stem waste. Ind Crop Prod 105: 74-82.

Omar NS, Bakar ES, Jalil N, Tahir P, Zin W, Yunus W. 2011. Distribution of oil palm starch for different levels and portions of oil palm trunk. Wood Res J 2 (2): 73-77.

Pei-lang AT, Mohamed AMD, Karim AA. 2006. Sago starch and composition of associated components in palms of different growth stages. Carbohydr Polym 63: 283-286.

Ridwansyah, Nasution MZ, Sunarti TC, Fauzi AM. 2010. Karakteristik sifat fisiko-kimia pati kelapa sawit. J Agroind Technol 17 (1): 1-6. [Indonesian]

Singh J, Singh N. 2003. Studies on the morphological and rheological properties of granular cold water soluble corn and potato starches. Food Hydrocoll 17: 63-72.

Singhal RS, Kennedy JF, Gopalakrishnan SM, Kaczmarek A, Knil CJ, Akmar PF. 2008. Industrial production, processing, and utilization of sago palm-derived products. Carbohydr Polym 72: 1-20. 
Suh DS, Jane Jl. 2003. Comparison of starch pasting properties at various cooking conditions using the Micro Visco-Amylo-Graph and the Rapid Visco Analyser. Cereal Chem 80 (6):745-749

Sulaiman O, Salim N, Nordin NA, Hashim R, Ibrahim M, Sato M. 2012. The potential of oil palm trunk biomass as an alternative source for compressed wood. BioResources 7 (2): 2688.

Thirumdas R, Trimukhe A, Deshmukh RR, Annapure US. 2017. Functional and rheological properties of cold plasma treated rice starch. Carbohydr Polym 157: 1723-1731.

Tomimura Y. 1992. Chemical characteristics of oil palm trunk. Wood Chem 5 (362): 133-142.
Tu AT, Lee J, Milanovich FP. 1979. Laser-Raman Spectroscopy study of cyclohexaamylose and related compounds: spectral analysis and structural implications. Carbohydr Res 76: 239-244.

Wang S, Zhou B, Wang Y, Li B. 2015. Preparation and characterization of konjac glucomannan microcrystals through acid hydrolysis. Food Res Int 67: 111-116

Xing X, Cui SW, Nie S, Phillips GO, Goff HD, Wang Q. 2014. Study on dendrobium officinale O-acetyl-glucomannan (Dendronan s): part I. extraction, purification, and partial structural characterization. Bioact Carbohydr Diet Fibre 4 (1): 74-83 